\title{
Investigation of the Relationship between Academic Self-Concept and Academic Self-Efficacy of University Students Receiving Sports Education
}

\author{
İsa Doğan (Corresponding Author) \\ Hasan Doğan School of Physical Education and Sports, Karabuk University, Turkey \\ E-mail: isadogan33@gmail.com
}

Gamze Durmuş

Health Sciences Institute, Gazi University, Turkey

E-mail: gamzeakca6706@gmail.com

Received: November 5, 2021 Accepted: December 5, 2021

Published: December 31, 2021

doi:10.5296/jei.v7i3.19269 URL: https://doi.org/10.5296/jei.v7i3.19269

\begin{abstract}
In this study, it was aimed to examine the relationship between Academic Self-Concept and Academic Self-Efficacy of university students studying in the field of sports sciences. The population of the research consists of a total of 619 students from the 2nd, 3rd, and 4th grades of Karabük University Hasan Doğan School of Physical Education and Sports, while the sample group consists of a total of 241 students, 88 of whom are female and 153 are male. "Personal Information Form", "Matovu Academic Self-Concept Scale" developed by Liu and Wang (2005) and later adapted for university students by Matovu (2014) and adapted into Turkish by Cantekin and Gökler (2019), and the "Academic Self-Efficacy Scale" developed by Kandemir (2010) were used as data collection tools in the research. The data obtained were analyzed with the SPSS-24 Package Program. At the same time, Pearson correlation analysis, Independent-Samples t-test analysis, One-Way ANOVA (One-Way Analysis of Variance), Tukey multiple comparison were used in the analysis and interpretation of the data. While there is a significant difference between the Academic Self-Efficacy Scale (ASES) and Self-Efficacy for Academic Effort, one of its sub-dimensions, according to the gender of the students, there is no significant difference between it and the other sub-dimensions. According to the grade levels of the students, there is a significant difference between the
\end{abstract}


total of ASES and Self-Efficacy for Handling Academic Problems, one of its sub-dimensions, while there is no significant difference between it and other sub-dimensions.

Keywords: Academic Self-Concept, Academic Self-Efficacy

\section{Introduction}

When we look at the literature, Academic Self-Concept and Academic Self-Efficacy concepts are confused with each other. However, there are differences both conceptually and functionally. First, while self-efficacy is cognitive, Academic Self-Concept includes affective and motivational domains as well as cognitive domains. Second, Academic Self-Concept reflects a more general perception, while self-efficacy is assessed through a specific activity. Third, Academic Self-Concept is retro-oriented while self-efficacy is future-oriented. Finally, students are asked to consult their own opinions on issues related to their own situation in the self-efficacy scale items, while students are asked to compare themselves with others in the Academic Self-Concept scale items (Ferla et al., 2009).

Again, since the concept of self and self are used interchangeably in the literature, these two concepts lead to confusion. According to Gecas (1982), who explains the distinction, the self reveals the dialectical process that is based on the discussions about whether it is the subject or the object of knowledge in philosophy. The self-concept is a product of this dialectical process. Human beings have always been concerned with understanding themselves and others. From this perspective, it is seen that efforts to understand and express one's self are as old as human history. Even when writing was not invented, it was tried to show the mood and own features to others through cave paintings. In ancient Greece, philosophers of the period (Socrates, Plato, Aristotle) associated the spiritual self with the concept of soul (Sorabji, 2006). The handling of the concept of self within the science of psychology begins with William James's The Principles of Psychology (1952/1891). In this work, the definition of "self is a representation of all that an individual knows about him/herself" is taken as a basis today (Pajares \& Schunk, 2002).

The part of the self-concept related to the student role and academic competence is defined as the Academic Self-Concept and it is an important factor affecting the learning processes and thus the success. Academic Self-Concept is as student's perceptions on himself/herself that are specific to different disciplines (Turkish, Social, etc.) or general academic field, and the argument $\mathrm{s} /$ he develops about how talented s/he is compared to other students (Marsh et al., 2008; Arseven, 1979). It is argued that the person's attitude towards him/herself and his/her academic self-perception are based on the judgments of his/her teachers, parents, friends and environment in his/her own learning history, and students who encounter failures at school also develop a negative attitude towards learning at school (Senemoğlu, 2003).

Another variable addressed in the study is Academic Self-Efficacy. First of all, it is useful to start by defining the concept of self-efficacy. The concept of Self-efficacy, based on Bandura's Social Learning Theory, is the belief of the individual to organize and implement the necessary activities in order to exhibit a certain performance (Bandura, 1995). Self-efficacy affects task choice, effort, patience, endurance, success, behavioral states and 
activities such as how long they can withstand obstacles and deterrents (Şeker, 2016; Yalmac1 $\&$ Aydin, 2014). People with high self-efficacy may be more comfortable and productive when faced with high-difficulty situations. People with low self-efficacy see difficult situations even harder than they really are, and such a thought increases anxiety and stress and narrows the person's perspective to solve the problem. In this direction, it is determined that self-efficacy strongly affects the success of individuals (Pajares, 2002).

This concept, which has developed in the field of social psychology, has started to be used in other disciplines and fields over time. One of them is the field of education and learning. According to Bandura, who connects Academic Self-Efficacy to Self-Efficacy theory, Academic Self-Efficacy is the belief that an individual can be successful in an academic subject area (Bandura, 1997). Academic Self-Efficacy focuses on the ability of individuals to successfully fulfill their academic duties and responsibilities (Booth, Abercrombie, \& Frey, 2017).

When the literature is examined, it is seen that the studies related to the Academic Self-Concept are mostly conducted with students at primary and secondary education level, and they refer to its relationships between academic achievement, attitude towards school and course, problem posing and solving skills (Korkmaz \& Kaptan, 2002; Yüksel, 2003; Deringöl, 2019). With the Matovu Academic Self-Concept scale developed in 2019, it has become possible to measure the Academic Self-Concepts of university students in Turkey (Cantekin \& Gökler, 2019). On the other hand, it is seen that studies on Academic Self-Efficacy are mostly conducted with teacher candidates, and the relations between Academic Self-Efficacy and academic motivation, academic success, academic procrastination are addressed (Albayrak, 2014; Şeker, 2016; Gündoğan \& Koçak, 2017). It is very difficult to encounter studies in which Academic Self-Concept and Academic Self-Efficacy are used together in national and international literature (Wang \& Neihart, 2015). In the field of physical education and sports sciences, no study was found in which both concepts were used together. For this reason, it is thought that due to the originality of the study, it will shed light on future studies.

\subsection{Purpose of the Research}

The aim of the study is to examine the relationship between Academic Self-Concept and Academic Self-Efficacy of university students studying in the field of sports sciences in terms of some variables. For this purpose, answers to the following questions were sought:

(1) Is there a relationship between the students' Academic Self-Concept and their Academic Self-Efficacy?

(2) Is there a significant difference between Matovu Academic Self-Concept and Academic Self-Efficacy according to the gender of the students?

(3) Is there a significant difference between Matovu Academic Self-Concept and Academic Self-Efficacy according to the departments of the students?

(4) Is there a significant difference between Matovu Academic Self-Concept and 
Academic Self-Efficacy according to the grade levels of the students?

\section{Method}

In this section, information about the research model, the sample group, the data collection tools and the analysis of the data are given.

\subsection{Research Model}

This research is an example of the relational screening model, which is one of the general screening models. In relational screening models, also called correlational, the co-variance of two or more variables is examined (Büyüköztürk, Çakmak, Akgün, Karadeniz, \& Demirel, 2016).

\subsection{Sample Group}

The population of the research consists of a total of 619 students from the $2 \mathrm{nd}$, 3rd, and 4th grades of Karabük University Hasan Doğan School of Physical Education and Sports, while the sample group consists of a total of 241 students, 88 of whom are female and 153 are male. When Table 1 is examined, the frequency and percentage distributions of the characteristics reflecting the personal knowledge of the students are seen.

Table 1. Demographic information of participants

\begin{tabular}{|l|l|l|l|}
\hline \multirow{4}{*}{ Gender } & Categories & $F$ & $\%$ \\
\hline \multirow{4}{*}{ Department } & Female & 88 & 36.5 \\
\cline { 2 - 4 } & Male & 153 & 63.5 \\
\hline \multirow{4}{*}{ Grade } & Physical Edu. and Sports Teac. & 91 & 37.8 \\
\cline { 2 - 4 } & Sports Management & 70 & 29.0 \\
\cline { 2 - 4 } & Coaching Training & 80 & 33.2 \\
\hline \multirow{2}{*}{ Total } & $2^{\text {nd }}$ Grade & 123 & 51.0 \\
\cline { 2 - 5 } & $3^{\text {rd }}$ Grade & 70 & 29.1 \\
\cline { 2 - 4 } & $4^{\text {th }}$ Grade & 48 & 19.9 \\
\hline
\end{tabular}

$36.5 \%(\mathrm{n}=88)$ of the students participating in the research were female, while $63.5 \%(\mathrm{n}=$ 153) were male, and $37.8 \%(\mathrm{n}=91)$ were physical education and sports teaching students, whereas $29.0 \%(n=70)$ were sports management students and $33.2 \%(n=80)$ were coaching education department students, and $51.0 \%(\mathrm{n}=123)$ were 2 nd grade students, while $29.1 \%(\mathrm{n}$ $=70)$ were 3 rd grade students and $19.9 \%(n=48)$ were 4 th grade students. 


\subsection{Data Collection Tools}

Within the scope of the research, data were collected through the "Personal Information Form", "Matovu Academic Self-Concept Scale" and "Academic Self-Efficacy Scale" Google Form.

\subsubsection{Personal Information Form}

The Personal Information Form developed by the researchers includes gender, department and grade level variables.

\subsubsection{Matovu Academic Self-Concept Scale}

The scale, developed by Liu and Wang (2005), later adapted for university students by Matovu (2014) and adapted into Turkish by Cantekin and Gökler (2019), consists of a total of 20 items collected in two dimensions: academic confidence and academic effort. The Cronbach Alpha internal consistency coefficients for the dimensions were obtained as 0.960 and 0.964 , respectively, by the researchers who adapted it into Turkish. The Cronbach Alpha internal consistency coefficient for the entire scale was calculated as 0.930. Factor loadings ranged from .722 to .963 , and adjusted item-total correlations ranged between .433-.800. There are reverse coded items in the scale.

\subsubsection{Academic Self-Efficacy Scale}

The scale developed by Kandemir (2010) consists of a total of 19 items collected in three sub-dimensions: self-efficacy for handling academic problems, self-efficacy for academic effort, and self-efficacy for academic planning. The Cronbach alpha internal consistency coefficients were found to be .90 for the first factor, .78 for the second factor, .77 for the third factor, and 92 for the whole scale by the researcher who developed the scale. There are no reverse coded items in the scale.

\subsection{Analysis of Data}

Within the scope of the research, first, the distribution of the data set was examined in line with the answers given by the students to the data collection tools. In this direction, first of all, the skewness and kurtosis coefficients were calculated. When the skewness-kurtosis coefficients calculated for the normality assumption of the variables were examined, it was determined that the coefficients took values between -2 and +2 (Matovu Academic Self-Concept Scale total: skewness $=-0.590$; kurtosis $=0.899$; Academic Confidence: skewness $=-0.440 ;$ kurtosis $=0.184$ and Academic Effort: skewness $=-0.652$; kurtosis $=$ 1.007 from the Matovu Academic Self-Concept Scale sub-dimensions; Academic Self-Efficacy Scale total: skewness = -0.505; kurtosis = 1,579; Self-efficacy for handling with academic problems: skewness $=-0.454$; kurtosis $=1.169$, self-efficacy for academic effort: skewness $=-0.599$; kurtosis $=1.782$, and self-efficacy for academic planning: skewness $=$ -0.465 ; kurtosis $=0.771$, which are among the Academic Self-Efficacy Scale Sub-Dimensions), and it was observed that the total and sub-dimensions of the Matovu Academic Self-Concept Scale and the Total and sub-dimensions of the Academic Self-Efficacy Scale showed normal distribution. In order to examine the assumption of 
normality, the histogram graph was also examined.

In Table 2, when examining the results of Levene statistic conducted to determine whether the score distributions of the scales are homogeneously distributed or not, it is seen that the scores obtained from the scales are homogeneously distributed.

Table 2. Skewness, Kurtosis and Levene homogeneity test results regarding the normality of the scores obtained by students from the scales

\begin{tabular}{|l|l|l|l|l|l|}
\hline \multirow{2}{*}{$\mathrm{N}=241$} & & \multirow{2}{*}{ Skewness } & \multirow{2}{*}{ Kurtosis } & \multicolumn{2}{|c|}{ Homogeneity Test } \\
\cline { 5 - 7 } & & & & Levene Statistics & $\mathrm{p}$ \\
\hline \multirow{4}{*}{ Matovu Academic Self-Concept Scale } & A. confidence & -0.440 & 0.184 & 1.618 & .205 \\
& A. effort & -0.652 & 1.007 & 2.363 & .126 \\
& Total & -0.590 & 0.899 & 1.547 & .215 \\
\hline \multirow{3}{*}{ Academic Self-Efficacy Scale } & Handling & -0.454 & 1.169 & 0.835 & .362 \\
& Effort & -0.599 & 1.782 & 0.270 & .604 \\
& Planning & -0.465 & 0.771 & 1.126 & .290 \\
& Total & -0.505 & 1.579 & 0.683 & .409 \\
\hline
\end{tabular}

When the structure of the score distributions obtained from the data collected from the students is examined, it is seen that it meets the assumptions of normality and homogeneity, it is scaled at an evenly spaced scale level, and it meets the assumptions of the parametric test since it is a data that shows continuous distribution (Köklü, Büyüköztürk, \& Bökeoğlu, 2007).

The relationship between the scores of the students from the scales was examined by Pearson correlation analysis. Independent-Samples t-test analysis was used to test the difference between the scores obtained from the scales according to the demographic characteristics (gender) of the students in two categories. One-Way ANOVA (One-Way Analysis of Variance) was used to test the difference between the scores obtained from the scales according to the demographic characteristics of the students (department, grade) with more than two categories, and Tukey Multiple Comparison was used to determine the differences. 


\section{Findings}

Table 3. Pearson correlation analysis results of the relationship between students' Matovu Academic Self-Concept Scale and Academic Self-Efficacy Scale and its sub-dimensions

\begin{tabular}{|l|l|l|l|l|l|}
\hline $\mathrm{N}=241$ & & Handling & Effort & Planning & Academic Self-Efficacy Scale \\
\hline \multirow{2}{*}{ Matovu Academic Self-Concept Scale } & $\mathrm{r}$ & $.591^{*}$ & $.516^{*}$ & $.576^{*}$ & $.629^{*}$ \\
\cline { 2 - 7 } & $\mathrm{p}$ & .000 & .000 & .000 & .000 \\
\hline
\end{tabular}

Note. ${ }^{*} \mathrm{p}<.05$ Categories $\mathrm{r}: 0-0.30=$ low relationship; $0.40-0.60=$ moderate relationship; $0.70-1.00=$ high level of relationship.

It was examined in Table 3 whether there is a relationship between the students' Matovu Academic Self-Concept Scale and Academic Self-Efficacy Scale and its sub-dimensions. According to $\mathrm{p}=.000<.05$, it is seen that there is a moderately significant positive relationship between "self-efficacy for handling academic problems" ( $\mathrm{r}=0.591)$, "self-efficacy for academic effort" $(\mathrm{r}=0.516)$ and "self-efficacy for academic planning" $(\mathrm{r}=$ 0.576), which are among the sub-dimensions of Matovu Academic Self-Concept Scale and Academic Self-Efficacy Scale. According to $p=.000<.05$, there is a moderately significant positive relationship between the students' total Matovu Academic Self-Concept Scale and Academic Self-Efficacy Scale $(r=0.629)$.

Table 4. Pearson Correlation Analysis Results of the Relationship between Students' Scores from Academic Self-Efficacy Scale and Matovu Academic Self-Concept Scale and its Sub-Dimensions

\begin{tabular}{|l|l|l|l|l|}
\hline $\mathrm{N}=241$ & & A. confidence & A. effort & Matovu Academic Self-Concept Scale \\
\hline \multirow{2}{*}{ Academic Self-Efficacy Scale } & $\mathrm{r}$ & $.619^{*}$ & $.503^{*}$ & $.629^{*}$ \\
\cline { 2 - 5 } & $\mathrm{p}$ & .000 & .000 & .000 \\
\hline
\end{tabular}

Note. ${ }^{*} \mathrm{p}<.05$ Categories $\mathrm{r}: 0-0.30=$ low relationship; $0.40-0.60=$ moderate relationship; $0.70-1.00=$ high level of relationship.

It was examined in Table 4 whether there is a relationship between the students' Academic Self-Efficacy Scale and the Matovu Academic Self-Concept Scale and its sub-dimensions. According to $\mathrm{p}=.000<.05$, it is seen that there is a moderately significant positive relationship between the academic confidence" $(r=0.619)$ and "academic effort" $(r=0.503)$, which are among the Academic Self-Efficacy Scale and Matovu Academic Self-Concept Scale sub-dimensions. According to $\mathrm{p}=.000<.05$, there is a moderately significant positive 


\section{Macrothink

relationship between total of the students from the Academic Self-Efficacy Scale and the Matovu Academic Self-Concept Scale $(r=0.629)$.

3.1 Is There a Significant Difference between Matovu Academic Self-Concept According to the Gender of the Students?

Table 5. Independent-samples t-Test results on the difference between Matovu Academic Self-Concept according to the gender of students

\begin{tabular}{|c|c|c|c|c|c|c|c|c|}
\hline & Gender & $\mathrm{N}$ & $\bar{X}$ & $\mathrm{~S}$ & $\mathrm{t}$ & sd & $\mathrm{p}$ & $\mathrm{d}$ \\
\hline \multirow{2}{*}{ A. confidence } & Female & 88 & 33.22 & 4.60 & \multirow{2}{*}{0.800} & \multirow{2}{*}{239} & \multirow{2}{*}{.425} & \multirow{2}{*}{0.1089} \\
\hline & Male & 153 & 37.68 & 5.29 & & & & \\
\hline \multirow{2}{*}{ A. effort } & Female & 88 & 36.62 & 4.27 & \multirow{2}{*}{1.659} & \multirow{2}{*}{239} & \multirow{2}{*}{.098} & \multirow{2}{*}{0.2283} \\
\hline & Male & 153 & 35.53 & 5.23 & & & & \\
\hline \multirow{2}{*}{ Matovu Academic Self-Concept Scale } & Female & 88 & 74.85 & 8.10 & \multirow{2}{*}{1.370} & \multirow{2}{*}{239} & \multirow{2}{*}{.172} & \multirow{2}{*}{0.1867} \\
\hline & Male & 153 & 73.22 & 9.31 & & & & \\
\hline
\end{tabular}

Table 5 shows that according to the gender of the students, no significant difference was found according to Matovu Academic Self-Concept $t=-1.370, p=.172>.05$ and its sub-dimensions Academic Confidence $\mathrm{t}=0.800, \mathrm{p}=.425>.05$, Academic Effort $\mathrm{t}=1.659, \mathrm{p}$ $=.98>.05$. The Cohen $\mathrm{d}$ value calculated for the effect size was found to be 0.1867 for the Matovu Academic Self-Concept Scale, 0.1089 for the Academic Confidence sub-dimension, and 0.2283 for the Academic Effort sub-dimension. 


\section{Macrothink}

3.2 Is There a Significant Difference between the Academic Self-Efficacy According to the Gender of the Students?

Table 6. Independent-samples T-Test results on the difference in Academic Self-Efficacy according to the gender of students

\begin{tabular}{|c|c|c|c|c|c|c|c|c|}
\hline & Gender & $\mathrm{N}$ & $\bar{X}$ & $\mathrm{~S}$ & $\mathrm{t}$ & sd & $\mathrm{p}$ & $\mathrm{d}$ \\
\hline \multirow{2}{*}{ Handling } & Female & 88 & 42.30 & 5.85 & \multirow{2}{*}{1.953} & \multirow{2}{*}{239} & \multirow{2}{*}{.052} & \multirow{2}{*}{0.2662} \\
\hline & Male & 153 & 40.60 & 6.88 & & & & \\
\hline \multirow{2}{*}{ Effort } & Female & 88 & 15.78 & 2.40 & \multirow{2}{*}{2.094} & \multirow{2}{*}{239} & \multirow{2}{*}{$.037^{*}$} & \multirow{2}{*}{0.2864} \\
\hline & Male & 153 & 15.03 & 2.82 & & & & \\
\hline \multirow{2}{*}{ Planning } & Female & 88 & 15.25 & 2.45 & \multirow{2}{*}{1.724} & \multirow{2}{*}{239} & \multirow{2}{*}{.086} & \multirow{2}{*}{0.2347} \\
\hline & Male & 153 & 14.64 & 2.74 & & & & \\
\hline \multirow{2}{*}{ Academic Self-Efficacy Scale } & Female & 88 & 73.34 & 9.45 & \multirow{2}{*}{2.133} & \multirow{2}{*}{239} & \multirow{2}{*}{$.034 *$} & \multirow{2}{*}{0.2930} \\
\hline & Male & 153 & 70.27 & 11.41 & & & & \\
\hline
\end{tabular}

Note. ${ }^{*} \mathrm{p}<.05$.

Table 6 shows that according to the gender of the students, there is a significant difference between Academic Self-Efficacy Scale $\mathrm{t}=2.133, \mathrm{p}=.034<.05$ and its sub-dimension, Self-Efficacy for Academic Effort, according to $t=2.094, p=.37<.05$. $t$ was determined that there was no significant difference between Self-Efficacy for Handling Academic Problems $t=1.953, p=.052>.05$ and Self-Efficacy for Academic Planning, which are its other sub-dimensions, according to $\mathrm{t}=1.724, \mathrm{p}=.0 .86>.05$. The Cohen $\mathrm{d}$ value calculated for the effect size was found to be 0.2930 for the Academic Self-Efficacy Scale, 0.2662 for the Self-Efficacy for Handling Academic Problems sub-dimension, and 0.2864 for the Self-Efficacy for Academic Effort sub-dimension, and 0.2347 for the Self-Efficacy for Academic Planning sub-dimension. 


\section{Macrothink}

Journal of Educational Issues

ISSN 2377-2263

2021, Vol. 7, No. 3, Special Issue

3.3 Is There a Significant Difference between Matovu Academic Self-Concept According to the Departments of the Students?

Table 7. One-way ANOVA (one-way analysis of variance) results on the difference between Matovu Academic Self-Concept according to the department of students

\begin{tabular}{|c|c|c|c|c|c|c|c|}
\hline & Department & $\mathrm{N}$ & $\bar{X}$ & S & $\mathrm{F}$ & sd & $\mathrm{p}$ \\
\hline \multirow{3}{*}{ A. confidence } & Physical Edu. and Sports Teac. & 91 & 38.21 & 4.93 & \multirow{3}{*}{0.343} & \multirow{3}{*}{239} & \multirow{3}{*}{.710} \\
\hline & Sports Management & 70 & 37.77 & 5.09 & & & \\
\hline & Coaching Training & 80 & 37.60 & 5.18 & & & \\
\hline \multirow{3}{*}{ A. effort } & Physical Edu. and Sports Teac. & 91 & 35.54 & 5.66 & \multirow{3}{*}{0.532} & \multirow{3}{*}{239} & \multirow{3}{*}{.588} \\
\hline & Sports Management & 70 & 35.98 & 4.14 & & & \\
\hline & Coaching Training & 80 & 36.32 & 4.66 & & & \\
\hline \multirow{3}{*}{$\begin{array}{l}\text { Matovu Academic } \\
\text { Self-Concept Scale }\end{array}$} & Physical Edu. and Sports Teac. & 91 & 73.76 & 9.54 & \multirow{3}{*}{0.009} & \multirow{3}{*}{239} & \multirow{3}{*}{.991} \\
\hline & Sports Management & 70 & 73.75 & 7.88 & & & \\
\hline & Coaching Training & 80 & 73.92 & 9.11 & & & \\
\hline
\end{tabular}

Table 7 shows that the students' Academic Self-Concept did not show a significant difference according to their departments $(\mathrm{p}>0.05)$. In other words, it was determined that the Academic Self-Concepts of the students studying in the physical education and sports teaching, sports management, and coaching education departments are similar. 
3.4 Is There a Significant Difference between the Academic Self-Efficacy According to the Departments of the Students?

Table 8. One-way ANOVA (one-way analysis of variance) results on the difference between Academic Self-Efficacy according to the departments of the students

\begin{tabular}{|c|c|c|c|c|c|c|c|}
\hline & Department & $\mathrm{N}$ & $\bar{X}$ & $\mathrm{~S}$ & $\mathrm{~F}$ & sd & $\mathrm{p}$ \\
\hline \multirow{3}{*}{ Handling } & Physical Edu. and Sports Teac. & 91 & 41.38 & 6.70 & \multirow{3}{*}{0.145} & 2 & \multirow{3}{*}{.865} \\
\hline & Sports Management & 70 & 41.38 & 5.95 & & 238 & \\
\hline & Coaching Training & 80 & 40.90 & 6.96 & & 240 & \\
\hline \multirow{3}{*}{ Effort } & Physical Edu. and Sports Teac. & 91 & 15.16 & 3.00 & \multirow{3}{*}{0.402} & 2 & \multirow{3}{*}{.670} \\
\hline & Sports Management & 70 & 15.54 & 2.40 & & 238 & \\
\hline & Coaching Training & 80 & 15.26 & 2.59 & & 240 & \\
\hline \multirow{3}{*}{ Planning } & Physical Edu. and Sports Teac. & 91 & 15.00 & 2.61 & \multirow{3}{*}{0.271} & 2 & \multirow{3}{*}{.763} \\
\hline & Sports Management & 70 & 14.87 & 2.68 & & 238 & \\
\hline & Coaching Training & 80 & 14.70 & 2.68 & & 240 & \\
\hline \multirow{3}{*}{ Academic Self-Efficacy Scale } & Physical Edu. and Sports Teac. & 91 & 71.54 & 11.39 & \multirow{3}{*}{0.154} & 2 & \multirow{3}{*}{.857} \\
\hline & Sports Management & 70 & 71.80 & 10.57 & & 238 & \\
\hline & Coaching Training & 80 & 70.86 & 10.92 & & 240 & \\
\hline
\end{tabular}

Table 8 shows that the Academic Self-Efficacy of the students does not differ significantly according to their departments $(\mathrm{p}>0.05)$. In other words, it was determined that the Academic Self-Efficacy of the students studying in physical education and sports teaching, sports management, and coaching education departments are similar. 
3.5 Is There a Significant Difference between Matovu Academic Self-Concept According to the Grade Levels of Students?

Table 9. One-way ANOVA (one-way analysis of variance) results on the difference between Matovu Academic Self-Concept according to the grade levels of students

\begin{tabular}{|c|c|c|c|c|c|c|c|}
\hline & Department & $\mathrm{N}$ & $\bar{X}$ & $\mathrm{~S}$ & $\mathrm{~F}$ & sd & $\mathrm{p}$ \\
\hline \multirow{3}{*}{ A. confidence } & $2^{\text {nd }}$ Grade & 123 & 38.53 & 4.68 & \multirow{3}{*}{2.352} & 2 & \multirow{3}{*}{.097} \\
\hline & $3^{\text {rd }}$ Grade & 70 & 36.94 & 5.76 & & 238 & \\
\hline & $4^{\text {th }}$ Grade & 48 & 37.58 & 4.70 & & 240 & \\
\hline \multirow{3}{*}{ A. effort } & $2^{\text {nd }}$ Grade & 123 & 36.43 & 4.93 & \multirow{3}{*}{1.349} & 2 & \multirow{3}{*}{.261} \\
\hline & $3^{\text {rd }}$ Grade & 70 & 35.32 & 4.80 & & 238 & \\
\hline & $4^{\text {th }}$ Grade & 48 & 35.32 & 5.04 & & 240 & \\
\hline \multirow{3}{*}{ Matovu Academic Self-Concept Scale } & $2^{\text {nd }}$ Grade & 123 & 74.97 & 8.39 & \multirow{3}{*}{2.272} & 2 & \multirow{3}{*}{.105} \\
\hline & $3^{\text {rd }}$ Grade & 70 & 72.27 & 9.70 & & 238 & \\
\hline & $4^{\text {th }}$ Grade & 48 & 73.10 & 8.72 & & 240 & \\
\hline
\end{tabular}

Table 9 shows that the Academic Self-Concept of the students does not show a significant difference according to their grade level $(\mathrm{p}>0.05)$. In other words, it was determined that the Academic Self-Concepts of the 1st, 2nd and 3rd grade students are similar. 
3.6 Is There a Significant Difference between the Academic Self-Efficacy According to the Grade Levels of Students?

Table 10. One-way ANOVA (one-way analysis of variance) results on the difference between Academic Self-Efficacy according to the grade levels of students

\begin{tabular}{|c|c|c|c|c|c|c|c|c|}
\hline & Department & $\mathrm{N}$ & $\bar{X}$ & S & $\mathrm{F}$ & sd & $\mathrm{p}$ & Significant Difference \\
\hline \multirow{3}{*}{ Handling } & $2^{\text {nd }}$ Grade & 123 & 41.66 & 6.14 & \multirow{3}{*}{3.403} & 2 & \multirow{3}{*}{$.035 *$} & \multirow{3}{*}{$2-3.3-2$} \\
\hline & $3^{\text {rd }}$ Grade & 70 & 39.58 & 6.66 & & 238 & & \\
\hline & $4^{\text {th }}$ Grade & 48 & 42.47 & 7.12 & & 240 & & \\
\hline \multirow{3}{*}{ Effort } & $2^{\text {nd }}$ Grade & 123 & 15.26 & 2.59 & \multirow{3}{*}{2.521} & 2 & \multirow{3}{*}{.083} & \\
\hline & $3^{\text {rd }}$ Grade & 70 & 14.90 & 2.68 & & 238 & & \\
\hline & $4^{\text {th }}$ Grade & 48 & 16.02 & 2.90 & & 240 & & \\
\hline \multirow{3}{*}{ Planning } & $2^{\text {nd }}$ Grade & 123 & 14.94 & 2.60 & \multirow{3}{*}{2.475} & 2 & \multirow{3}{*}{.086} & \\
\hline & $3^{\text {rd }}$ Grade & 70 & 14.34 & 2.60 & & 238 & & \\
\hline & $4^{\text {th }}$ Grade & 48 & 15.41 & 2.75 & & 240 & & \\
\hline \multirow{3}{*}{ Academic Self-Efficacy Scale } & $2^{\text {nd }}$ Grade & 123 & 71.86 & 10.16 & \multirow{3}{*}{3.458} & 2 & \multirow{3}{*}{$.033 *$} & \multirow{3}{*}{$2-3.3-2$} \\
\hline & $3^{\text {rd }}$ Grade & 70 & 68.82 & 10.74 & & 238 & & \\
\hline & $4^{\text {th }}$ Grade & 48 & 73.91 & 11.98 & & 240 & & \\
\hline
\end{tabular}

Note. $* \mathrm{p}<.05$ Categories: $2^{\text {nd }}$ Grade $=1 ; 3^{\text {rd }}$ Grade $=2 ; 4^{\text {th }}$ Grade $=3$.

Table 10 shows that there is a significant difference according to $F(2-240)=3.403, p=.035$ $<.05$ between students' grade levels and their self-efficacy for handling academic problems, which is the sub-dimension of Academic Self-Efficacy scale. This significant difference stems from the fact that the students in the 4th grade $(=42.47)$ have higher self-efficacy scores for handling academic problems than the students in the 3rd grade $(=39.58)$. It is seen that there is no significant difference between the grade levels of the students and self-efficacy for academic effort $\mathrm{F}(2-240)=2.521, \mathrm{p}=.083>.05$ and self-efficacy for academic planning, which are among the Academic Self-Efficacy scale sub-dimensions, according to $\mathrm{F}(2-240)=2.475, \mathrm{p}=.086>.05$. It is seen that there is a significant difference between the grade levels of the students and the total of the Academic Self-Efficacy scale according to $\mathrm{F}(2-240)=3.458, \mathrm{p}=.033<.05$. This significant difference stems from the fact that students in the 4 th grade $(=73.91)$ have higher Academic Self-Efficacy scores than the students in the 3 rd grade $(=68.82)$. 


\section{Discussion}

In this study, it is aimed to examine the relationship between Academic Self-Concept and Academic Self-Efficacy of university students studying in the field of sports sciences. At the same time, the distinction between the concepts of Academic Self-Concept and Academic Self-Efficacy, which causes conceptual confusion in the literature, has been tried to be explained and it is thought that awareness has been created in the participants.

According to the gender variable, it was determined that there was no significant difference in terms of Academic Self-Concept of university students. In this case, it can be argued that regardless of male or female, they show improvement in their perceptions of themselves and how talented they are compared to other students within the scope of the general academic field. A comparison could not be made as there was no study on university students. According to the gender variable, a significant difference was found between the total of Academic Self-Efficacy and the self-efficacy for academic effort sub-dimension, but no difference was found in terms of the other sub-dimensions. This is a difference in favor of women. It can be thought that this means that women can better focus on the issue of successfully fulfilling their academic duties and responsibilities. While there are studies supporting this result in different studies (Durdukoca, 2010; Biricik, 2015; Uslu, 2018), there are also studies with opposite results (Çuhadar et al., 2013; Yalmacı \& Aydın, 2014; Şeker, 2016).

It was determined that there was no significant difference in terms of Academic Self-Concept of university students according to the department. Since there is no study on university students, a comparison could not be made. No significant difference was found in terms of Academic Self-Efficacy of university students according to the department. It can be understood that students studying in physical education teaching, coaching education and sports management departments show similarities in terms of their interest in academic subjects specific to their fields, their ability to make comparisons, their way of taking academic duties and responsibilities, etc. The study named Akdeniz University example, which was conducted by Eroğlu et al. (2017) to examine the relationship between Academic Self-Efficacy and academic motivation levels of students in the faculty of sports sciences, supports our research. In Biricik's (2015) study, "Examination of the Academic Self-Efficacy of students studying in physical education and sports departments," it is seen that there is a statistically significant difference according to the department variable, and this is an opposite result with our study.

It was determined that there is no significant difference in terms of Academic Self-Concept of university students according to grade level. Since there is no study on university students, a comparison could not be made. While it is seen that there is a significant difference between the total of the Academic Self-Efficacy scale and its sub-dimension of the self-efficacy for handling academic problems, according to the grade level, there was no significant difference between self-efficacy for academic effort and self-efficacy for academic planning, which are among the Academic Self-Efficacy scale sub-dimensions. However, when the literature is examined, there are studies that do not support the result of this research according to the 
grade variable (Cihan, 2014; Eroğlu et al., 2017; Uslu, 2018).

As a result, in this study, the relationship between Academic Self-Concept and Academic Self-Efficacy of university students receiving sports education was tried to be examined in terms of gender, department and grade level variables. In future research, Academic Self-Concept and self-efficacy of students studying at different universities can be determined and compared with each other. In addition to Academic Self-Concept and Academic Self-Efficacy of university students, the effect of other variables such as motivation, learning strategies, academic achievement, etc. can also be investigated.

\section{References}

Albayrak, E. (2014). Üniversite öğrencilerinde beş faktör kişilik, akademik öz-yeterlik, akademik kontrol odăgl ve akademik erteleme (Master's thesis, Karadeniz teknik Üniversitesi Eğitim Bilimleri Enstitüsü, Trabzon).

Arseven, D. A. (1979). Akademik benlik tasarımı ile akademik başarı arasındaki ilişki konusunda bir inceleme (Yayınlanmamış Doçentlik tezi, Hacettepe Üniversitesi, Ankara).

Bandura, A. (1997). Self efficacy: Exercises of control. New York: Freeman.

Biricik, Y. (2015). Beden eğitimi ve spor bölümlerinde öğrenim gören öğrencilerin akademik öz yeterliklerinin incelenmesi (Master's thesis, Atatürk Üniversitesi Sosyal Bilimler Enstitüsü, Erzurum).

Booth, M. Z., Abercrombie, S., \& Frey, C. J. (2017). Contradictions of adolescent self-construal: Examining the interaction of ethnic identity, self-efficacy and academic achievement. Mid-Western Educational Researcher, 29(1), 3-19.

Büyüköztürk, Ş., Çakmak, E. K., Akgün, Ö. E., Karadeniz, Ş., \& Demirel, F. (2016). Bilimsel araştırma yöntemleri. Ankara: PegemA Akademi. https://doi.org/10.14527/9789944919289

Cantekin, Ö. F., \& Gökler, R. (2019). Matovu akademik benlik kavramı ölçeğinin Türkçeye uyarlanmas1. Social Sciences, 14(4), 1355-1366. https://doi.org/10.29228/TurkishStudies. 22993

Cihan B. B. (2014). Beden eğitimi ve spor yüksekokulu öğretmenlik bölümünde öğrenim gören ögrrencilerin akademik, sportif ve ögretmenlik özyeterlik algılarının incelenmesi (Doktora Tezi, Gazi Üniversitesi, Eğitim Bilimleri Enstitüsü, Ankara).

Çuhadar, C., Gündüz, Ş., \& Tanyeri, T. (2013). Bilgisayar ve öğretim teknolojileri bölümü öğrencilerinin ders çalışma yaklaşımlarının ve akademik öz-yeterlik algılarının incelenmesi. Mersin Üniversitesi Ĕ̈itim Fakültesi Dergisi, 9(1), 251-259.

Dadand1, İ. (2018). Genel yetenek, akademik benlik kavramı, akademik öz-yeterlik, benlik saygısı, öğrenci bă̆lılı̆̆ ve akademik başarı arasındaki ilişkiler. Karadeniz Teknik Üniversitesi Eğitim Bilimleri Enstitüsü, Trabzon.

Deringöl, Y. (2019). İlkokul dördüncü sınıf öğrencilerinin problem kurma ve çözme becerileri ile akademik benlik durumları. Akdeniz Ĕ̆itim Araştırmaları Dergisi, 13(29), 172-187. 
https://doi.org/10.29329/mjer.2019.210.10

Ferla, J., Valcke, M., \& Cai, Y. (2009). Academic Self-Efficacy and Academic Self-Concept: Reconsidering structural relationships. Learning and Individual Differences, 19, 499-505. https://doi.org/10.1016/j.lindif.2009.05.004

Fırat Durdukoca, Ş. (2016). Sınıf öğretmeni adaylarının akademik özyeterlik algılarının çeşitli değişkenler açısından incelenmesi. Abant İzzet Baysal Üniversitesi Eğitim Fakültesi Dergisi, 10(1), 69-77. https://doi.org/10.21666/muefd.332430

Gecas, V. (1982). The self-concept. Annual Review of Sociology, 8(1), 1-33. https://doi.org/ 10.1146/annurev.so.08.080182.000245

Gündoğan, A., \& Koçak, A. (2017). Öğretmen adaylarının okul iklimi algıları ile akademik öz-yeterlik inançları arasındaki ilişkinin incelenmesi. Sakarya University Journal of Education, 7(3), 639-657. https://doi.org/10.19126/suje.333266

Korkmaz, H., \& Kaptan, F. (2002). Fen eğitiminde proje tabanlı öğrenme yaklaşımının ilköğretim öğrencilerinin akademik başarı, akademik benlik kavramı ve çalışma sürelerine etkisi. Hacettepe Üniversitesi Eğitim Fakültesi Dergisi, 22(22), 91-97.

Marsh, H. W., Seaton, M., Trautwein, U., Lüdtke, O., Hau, K. T., O’Mara, A. J., \& Rhonda, G. C. (2008). The big-fish-little-pond-effect stands up to critical scrutiny: implications for theory, methodology, and future research. Educ. Psychol. Rev., 20, 319-350. https://doi.org/10.1007/ s10648-008-9075-6

Pajares, F. (2002). Overview of Social Cognitive Theory and of Self-Efficacy. Retrieved October 1, 2021, from http://www.emory.edu/EDUCATION/mfp/eff.html

Pajares, F., \& Schunk, D. H. (2002). Self and self-belief in psychology and education: An historical perspective. In J. Aronson (Ed.), Improving academic achievement (pp. 5-22). New York: Academic Press. https://doi.org/10.1016/B978-012064455-1/50004-X

Şeker, S. S. (2017). Müzik eğitimi bölümü öğretmen adaylarının akademik güdülenme ve akademik öz-yeterlik düzeylerinin incelenmesi. Abant İzzet Baysal Üniversitesi Ĕgitim Fakültesi Dergisi, 17(3), 1465-1484. https://doi.org/10.17240/aibuefd.2017.17.31178-338840

Senemoğlu, N. (2003). Gelişim, ögrenme ve ögretim (8th ed.). Ankara: Kalkan Matbaacılık.

Sorabji, R. (2006). Time, creation, and the continuum: Theories in antiquity and the early middle ages. University of Chicago Press, USA.

Uslu, T. (2018). Üniversite ögrencilerinin liderlik, akademik özyeterlik ve okula yabancılaşma algıları (Erzincan örneği). İnönü Üniversitesi Eğitim Bilimleri Enstitüsü, Malatya.

Wang, C. W., \& Neihart, M. (2015). Academic Self-Concept and Academic Self-Efficacy: Self-beliefs enable academic achievement of twice-exceptional students. Roeper Review, 37(2), 63-73. https://doi.org/10.1080/02783193.2015.1008660 


\section{Macrothink

Yalmacı, S. G., \& Aydın, S. (2014). Fen bilgisi öğretmen adaylarının akademik öz-yeterlik algilarının incelenmesi. e-Kafkas Journal of Educational Research, 1(2), 21-27.

Yüksel, A. (2003). Lise birinci sınıf ögrencilerinin öğrenilmiş çaresizlik düzeylerinin akademik benlik tasarımları, okula karşı tutumları ve akademik başarıları üzerindeki etkisi (Master's thesis, Yıldız Teknik Üniversitesi Sosyal Bilimler Enstitüsü, İstanbul).

\section{Copyright Disclaimer}

Copyright for this article is retained by the author(s), with first publication rights granted to the journal.

This is an open-access article distributed under the terms and conditions of the Creative Commons Attribution license (http://creativecommons.org/licenses/by/3.0/). 